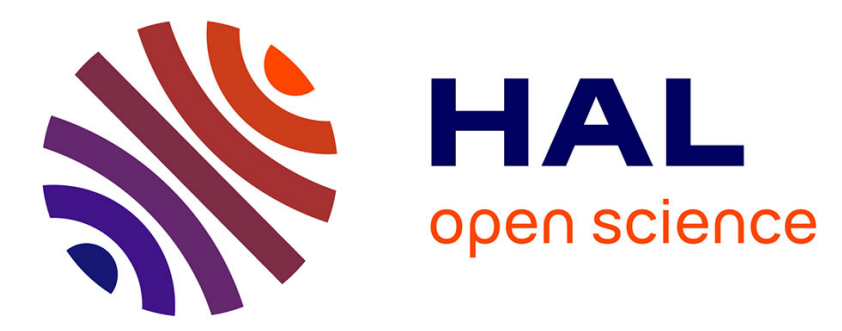

\title{
Early lineages of Vespidae (Hymenoptera) in Cretaceous amber:
}

\author{
Adrien Perrard, David Grimaldi, James M. Carpenter
}

\section{To cite this version:}

Adrien Perrard, David Grimaldi, James M. Carpenter. Early lineages of Vespidae (Hymenoptera) in Cretaceous amber: . Systematic Entomology, 2017, 42 (2), pp.379-386. 10.1111/syen.12222 . hal-01587206

\author{
HAL Id: hal-01587206 \\ https://hal.science/hal-01587206
}

Submitted on 13 Sep 2017

HAL is a multi-disciplinary open access archive for the deposit and dissemination of scientific research documents, whether they are published or not. The documents may come from teaching and research institutions in France or abroad, or from public or private research centers.
L'archive ouverte pluridisciplinaire HAL, est destinée au dépôt et à la diffusion de documents scientifiques de niveau recherche, publiés ou non, émanant des établissements d'enseignement et de recherche français ou étrangers, des laboratoires publics ou privés. 


\title{
Early lineages of Vespidae (Hymenoptera) in Cretaceous amber
}

(Preprint version of August 2016)

Perrard, A. Division of Invertebrate Zoology, American Museum of Natural History, $79^{\text {th }}$ Street at Central Park West, New York, 10024 NY, USA.

Present address: UMR 7204 CESCO, Museum National d'Histoire Naturelle, 61 Rue Buffon, 75005, Paris, France.

Grimaldi, D. Division of Invertebrate Zoology, American Museum of Natural History, $79^{\text {th }}$ Street at Central Park West, New York, 10024 NY, USA.

Carpenter, J.M. Division of Invertebrate Zoology, American Museum of Natural History, $79^{\text {th }}$ Street at Central Park West, New York, 10024 NY, USA.

\begin{abstract}
Three wasp (Hymenoptera: Vespidae) fossils in Cretaceous amber (Late Albian) of northern Myanmar are described. Two are new species of the Mesozoic genus Curiosivespa (Rasnitsyn): C. zigrasi sp.n. and C. striata sp.n.. The third species, Protovespa haxairei gen.n. et sp.n., has a combination of features unique among Mesozoic Priorvespinae and the extant subfamilies. These well-preserved fossils provide new morphological data for a cladistic analysis of the basal lineages of Vespidae. Results suggest that Euparagiinae is the sister group of all other Vespidae. The new genus Protovespa appears more closely related to extant Masarinae, Eumeninae and social wasps than to Priorvespinae. We assign it to a new subfamily: Protovespinae. Finally, fossil information combined with a phylogenetic tree show that the main groups of Vespidae likely evolved during the Early Cretaceous.
\end{abstract}

\section{Short title.}

Vespidae in Cretaceous amber 


\section{Introduction}

Social wasps are part of the family Vespidae (Hymenoptera) along with a huge diversity of solitary species. Their range of social behaviour, diversity of nest architecture and ecological importance make this group one of the best-studied families of wasps (e.g., Ross \& Matthews, 1991, Turillazzi \& West-Eberhard, 1996, Turillazzi, 2012, Archer, 2012). The fossil record indicates that the family evolved at least by the Early Cretaceous, with two genera (Curiosivespa Rasnitsyn and Priorvespa Carpenter \& Rasnitsyn) preserved as lithified remains from the Early Cretaceous deposits of Russia and Mongolia (Carpenter \& Rasnitsyn, 1990). However, the early history of this family is still poorly understood, since all of the Early Cretaceous fossils until now are known only as fragmentary compressions, mostly as wings. Of the several phylogenetic studies of Vespidae, only one considered the past diversity of deep relationships of the family (Carpenter \& Rasnitsyn, 1990). Three well-preserved Vespidae fossils recently found in Burmese amber add significant new knowledge on the early lineages of the Vespidae and our view of the evolution of the group.

Vespidae is organized into six extant subfamilies. Three subfamilies are comprised of solitary wasps: Euparagiinae, once a widespread and diverse group of which only one genus remains today with 10 nearctic species (Carpenter \& Kimsey, 2009); Masarinae, which feed on flower pollen (370 spp.) and the highly species-rich subfamily Eumeninae, or potter wasps (3746 spp.). The three other subfamilies are Stenogastrinae, primitively social wasps from South East Asia (63 spp.), Polistinae, or paper wasps, the most diverse group of social wasps (1003 spp.) and Vespinae, including yellow jackets and hornets (70 spp.). In addition to this extant diversity, 58 fossil species from four subfamilies have been described (Supplementary material, Table S.1). Six of these taxa belong to an extinct subfamily, Priorvespinae, previously known entirely as compression fossils (Carpenter \& Rasnitsyn, 1990).

Several attempts at reconstructing the phylogenetic history of this group have resulted in disparate hypotheses, especially regarding the evolution of sociality (e.g., Carpenter, 1981; Hines et al., 2007; Pickett \& Carpenter, 2010; Piekarski et al., 2014). The best-supported hypothesis placed Euparagiinae at the base of the family and Eumeninae as sister to a clade comprised of the three social subfamilies (Pickett \& Carpenter, 2010; Piekarski et al., 2014). The analysis including Priorvespinae presented similar relationships, with the Priorvespinae as sister group to the extant Vespidae (Carpenter \& Rasnitsyn, 1990). These results raise the question as to whether Priorvespinae can be considered as a crown Vespidae or as a stem group taxon for the family. That previous study was based on a limited number of morphological characters, since fossil characters were drawn mostly from the wings. Here, we 
test whether an analysis using new fossils, 3-dimensionally preserved with microscopic details and a significant number of characters, better resolves the position of the early lineages of Vespidae. In this study, we describe these new fossils from Burmese amber and we include them in a phylogenetic context based on samples from every tribe of the family.

\section{Material and methods}

The three fossils are from the Cretaceous amber deposit of the Hukawng Valley of Kachin State, northern Myanmar $\left(26^{\circ} 15^{\prime} \mathrm{N}, 96^{\circ} 34^{\prime} \mathrm{E}\right)$. The formation is dated from between the Early Cenomanian (Shi et al., 2012) to the Late Albian (99-105 Mya; Cruikshank \& Ko, 2003; Grimaldi \& Ross, 2016).

We follow here the wing venation nomenclature of Vespidae as described in Carpenter (1981), with abbreviations: $A$ anal vein; $C$ costal vein; $C u$ cubital vein; $M$ median vein; $R$ radial vein; $R_{l}$ first radial; $R_{S}$ radial sector; $S c$ subcostal vein; $1 c u$ - $a$ crossvein between $M$ and $C u_{1} ; 2 r-m$ and $3 r-m$ crossveins between $R_{S}$ and $M ; 1 m-c u$ and $2 m-c u$ crossveins between $M$ and $C u_{1} ; r 2$ crossvein between $R_{S}$ and $R_{1}$.

The relationship of these fossils to other Vespidae was explored through a cladistic analysis of 75 morphological and behavioural characters (Supplementary material, Table S.2). When possible, these characters were coded for the three vespid fossil genera from the Mesozoic. Two outgroups, Tiphiidae and Rhopalosomatidae, were selected because of shared characteristics with the new fossils; namely a relatively complete venation and presence of emarginate eyes. The characters of the fossil genera Curiosivespa and Priorvespa were based on the descriptions of every species known for these groups. Priorparagia is known from a single fossil ( $P$. anancites Brothers \& Rasnitsyn, 2008). Several species and genera were observed per extant subfamily, but the morphological matrix was based on 14 species selected to represent the morphological diversity of every tribe of Vespidae. Similarly, the two outgroups were coded based on the species Pseudotiphia beckeri (Tournier) and Rhopalosoma nearcticum Brues. A phylogenetic analysis was performed under parsimony using TNT (Goloboff et al., 2008), using 'implicit enumeration' and implied weighting (Goloboff, 1993). The concavity value K was set at 4.765625 using the script setk.run (J. S. Arias, pers. comm.). Node support was computed as GC-values from symmetric resampling of 10,000 replicates of traditional searches (group supported/contradicted values; Goloboff et al., 2003: GC-values are the differences in group frequency between the group found in the most parsimonious tree 
and the most frequent contradictory group). Only supported groups are shown (support value above zero, scaled 0-100).

\section{Taxonomy}

Family Vespidae Laicharting.

Subfamily Protovespinae Perrard \& Carpenter, subfam. n.

Etymology. Named after proto, 'first', and genus Vespa. Gender feminine.

Type genus. Protovespa Perrard \& Carpenter, gen. n.

Diagnosis: Forewing first discal cell shorter than subbasal, unlike other Vespidae except Priorvespinae and Gayellini. Hindwing $C u$ diverges basal to $c u-a$, unlike Gayellini. Forewing recurrent veins reaching $\mathrm{M}$ in the same cell, $3 r-m$ not sinuous, metasoma with first segment of similar width to second segment, unlike Priorvespinae.

Genus Protovespa Perrard \& Carpenter, gen. n.

Type species. Protovespa haxairei Perrard \& Carpenter, sp. n.

Description: Posterior part of head more produced dorsally than ventrally. Forewing venation reaching apex of wing, forewing subdiscal cell not produced, three submarginal cells present, third sub-marginal cell with anterior margin longer than posterior margin; apex of marginal cell pointed, touching margin of wing; vein $1 \mathrm{cu}-\mathrm{a}$ long, not curved.

Protovespa haxairei Perrard \& Carpenter, sp. n.

(Figs. $1 \& 2$ )

Material examined. Holotype, AMNH JZC-Bu1837 in the Division of Invertebrate Zoology, AMNH, New York.

Locality. MYANMAR, Kachin state, Cretaceous amber deposit of the Hukawng Valley. Early Cenomanian to Late Albian.

Etymology. Species named after Jean Haxaire, passionate entomologist and first mentor of AP.

Description. Female. Gena more produced in upper part than in lower part. Antenna with 12 articles. Scape longer than first flagellomere. Antennal flagellomeres short, approximately as wide as long. Eyes broadly emarginate. Ocelli closer to each other than to compound eyes. Clypeus wider than long, apex broken but without latero-apical teeth. Labrum protruding, pointed, with long setae. Mandible with small cutting edge. Occipital carina present, 
potentially extending to mandible. Labial palp with 3 segments, without long setae on the terminal segment. Mesosoma relatively short, slightly longer than wide, dorsally rounded; pronotal carina absent; posterior pronotal lobe a distance of 1.5 times its length from posterior angle of pronotum; precoxal suture present; mesonotum with notauli and parapsidal furrows distinct; parategula absent; tegula rounded, longer than wide; transscutal furrow longitudinally ridged; scutellum laterally compressed; metanotum and propodeum almost vertical; lateral surfaces of propodeum produced posteriorly. Metasoma with six segments, last four segments partially retracted into second one; first tergum not fused to first sternum; second sternum with deep punctation; sixth sternum laterally compressed into a furrow around sting. Legs with trochanter longer than wide; tarsomeres symmetrical; claws large with small basal tooth and thinner, hooked apex; foreleg with one tibial spur; mid- and hind legs with two tibial spurs; hind leg spurs asymmetrical, larger spur with short comb. Forewing not plaited longitudinally, with three submarginal cells; $1 \mathrm{cu}-\mathrm{a}$ long and nearly straight, received at fork of $M$ and $C u$; subdiscal cell not produced apically; $R s+M$ longer than abscissa of $M$ between $M+C u$ and $R s$; recurrent veins both received in second submarginal cell; $M$ segment between $1 m-c u$ and $2 m-c u$ longer than segment between $R s$ and $1 m-c u$; pterostigma long, subtruncate apically; $R s$ angled far from pterostigma, then straight; $R s$ between $2 r-m$ and $3 r-m$ longer than $2 r$-rs and apical segment of $R s$; marginal cell elongate with apex pointed, no appendix; $2 r-m$ curved; basal angle of marginal cell acute; $A, M$ and $C u$ veins almost reaching edge of membrane. $\mathrm{M}+\mathrm{Cu}, \mathrm{Cu}, \mathrm{Im}-\mathrm{cu}$ and $\mathrm{M}$ not aligned in straight line; first discal cell of similar size to subbasal cell, basal angle of first submarginal cell acute, angle between $R s$ and prestigma obtuse, second submarginal cell narrowed above with basal angle acute, $2 m$-cu close to $2 r-m, 3 r-m$ gently curved, apical part of $1 m-c u$ not angled, slightly curved, prestigma shorter than pterostigma. Hind wing with three closed cells; jugal lobe present; axillary incision deep; subbasal cell broadest subapically, $c u-a$ angled with $A, C u$ diverging basad of $c u-a, A$ with free abscissa present; hamuli not present before divergence between $R s$ and $R_{1}$. Measurements (mm): Forewing length: 8.6; Head width: 2.6; Head dorsal length: 1.25; Face height (top of the head to tip of the clypeus): 2.3; Mesosoma width: 2.4; Mesosoma length: 3.4 .

Male and larvae: unknown for this species.

\section{Subfamily Euparagiinae Ashmead}

The two new species are classified as Euparagiinae based on their apically produced subdiscal cell, a distinctive apomorphy of the subfamily. 
Genus Curiosivespa Rasnitsyn

The two new species are attributed to the genus Curiosivespa based on a combination of the reception of $1 c u-a$ at or after the divergence of $M$ and $C u$, the relatively straight $1 c u-a$ and the long first abscissa of $R s$, excluding Euparagia and Priorparagia. In addition, C. zigrasi possesses elongated antennal flagellomeres, as does Curiosivespa curiosa Rasnitsyn. The second and third submarginal cells of $C$. striata are also of subequal size, excluding Euparagia, while the marginal cell is apically produced, excluding Priorparagia.

Curiosivespa zigrasi Perrard \& Carpenter, sp. n.

(Figs. $3 \& 4$ )

Material examined. Holotype, AMNH JZC-Bu245 (James Zigras leg.), in the Division of Invertebrate Zoology, AMNH, New York.

Locality. MYANMAR, Kachin state, Cretaceous amber deposit of the Hukawng Valley. Early Cenomanian to late Albian.

Etymology. Species named after James Zigras, collector of the specimen.

Diagnosis: Forewing recurrent veins received in separate cells, unlike $C$. derivata and $C$. orapa. Crossvein $1 \mathrm{~m}$-cu sharply angled into second submarginal cell, unlike $C$. derivata and C. antiqua. Reception of $1 c u-a$ at fork of $M$ and $C u$, unlike $C$. curiosa, C. magna and $C$. striata. In addition, pterostigma very short (absent on wing depicted in Fig. 4), unlike every other Curiosivespa species except $C$. derivata.

Description. Sex: possibly female based on number of antennal articles. Antenna with 12 articles, scape shorter than first flagellomere, flagellomeres longer than wide. Pronotum with dorsal part short; mesoscutum longer than wide, scutellum dorsally produced, compressed laterally and convex posteriorly, produced over metanotum; propodeum with posterolateral spine produced. Legs with basitarsomere very long ( $>2 x$ length of tarsomere 2$)$; claws broad with small basal tooth. Metasoma with short first segment. Forewing not plaited longitudinally; first abscissa of $M$ longer than $R s+M$; first subdiscal cell produced apically; abscissa of $\mathrm{Cu}$ beyond $1 \mathrm{~m}$ - $\mathrm{cu}$ almost aligned with $1 \mathrm{~m}$ - $\mathrm{cu}$; first discal cell longer than subbasal cell; basal angle of first submarginal cell acute; recurrent veins received in separate cells; pterostigma very short, shorter than prestigma and truncate apically; angle between $R s$ and prestigma obtuse; apical part of $1 m$ - $c u$ angled; Rs angled close to middle of marginal cell. Hind wing with three closed cells; $c u-a$ vein received at fork of $M$ and $C u$; hamuli present 
basad of divergence of $R_{l}$ and $R s$. Measurements (in mm): Forewing (approximate) length: 16.5; Head width: 4.7; Mesosoma width: 4.4; Mesosoma length: 8.4.

Curiosivespa striata Perrard \& Carpenter, sp. n.

(Figs. $5 \& 6$ )

Material examined. Holotype, AMNH JZC-Bu1839 in the Division of Invertebrate Zoology, AMNH, New York.

Locality. MYANMAR, Kachin state, Cretaceous amber deposit of the Hukawng Valley. Early Cenomanian to Late Albian.

Etymology. Derived from the Latin 'striatus', based on the ridges observed on the sides of the specimen. This striation might be a taphonomic artefact, although it is difficult to assess based on a single fossil.

Diagnosis. Forewing recurrent veins received in separate cells, unlike $C$. derivata and $C$. orapa. Connection between $C u$ and $1 c u-a$ after the divergence of $M$ and $C u$, unlike $C$. antiqua, $C$. derivata and $C$. zigrasi. Second submarginal cell slightly higher than long, with basal angle obtuse, unlike C. curiosa and C. magna.

Description. Female. Head more developed in upper part; eyes emarginate; ocelli not visible; antenna with scape longer than first flagellomere. Pronotum without pronotal carina, lateral part vertical; pretegular carina with perpendicular marking; mesoscutum longer than wide; parategula absent; transscutal furrow smooth; scutellum compressed laterally and expanded posteriad over metanotum; metanotum vertical; mesepisternum striate; propodeum with lateral expansions wide and rounded; no valvula. Strong bristles present on legs, especially on tarsomeres; basitarsomere very long ( $>2 \mathrm{x}$ length of tarsomere 2$)$; each claw with a very elongate and straight basal tooth or a strong bristle, issuing from base of claw. Metasoma with six segments; first segment short; lateral parts of terga longitudinally striate.

Forewing not longitudinally plaited; first discal cell longer than subbasal cell; basal angle of first submarginal cell acute; vein $1 c u-a$ distal to fork of $M$ and $C u ; R s+M$ longer than abscissa of $M$ between $M+C u$ and $R s ; 1 c u-a$ long but not markedly curved; abscissa of $C u$ beyond $1 \mathrm{~m}$ $c u$ strongly recurrent, almost aligned with $1 m-c u$; pterostigma short, approximately same length as prestigma; pterostigma truncate apically; angle between $R s$ and prestigma obtuse; apical part of $1 m$ - $c u$ angled; recurrent veins received in separate cells; Rs between $1 r-m$ and $2 r-m$ approximately of same length as $2 r-r s$ and as the apex of $R s ; 1 r-m$ straight; marginal cell with apex rounded, with appendix present; $R s$ angled close to middle of marginal cell; $M$ and $C u$ veins almost reaching edge of membrane. Hind wing with three closed cells; $c u-a$ vein 
received at fork of $M$ and $C u$; hamuli present basal to divergence between $R_{l}$ and $R s$. Measurements (in mm): Forewing length: 8.4; Head width: 2.6; Mesosoma width: 1.9; Mesosoma length: 3.2 .

\section{Phylogenetic analysis}

A phylogenetic analysis of the 75 characters (Supplementary material, Table S.2) resulted in two trees (score of weighted characters: 16.812; consistency index (unweighted characters): 0.427; retention index (unweighted characters): 0.669). The two trees differed in how Curiosivespa was resolved within Euparagiinae, the genus being unresolved in the consensus (Fig. 7). Euparagiinae was recovered as the sister clade to the rest of Vespidae, instead of Priorvespinae. This novel arrangement was mostly supported by synapomorphies shared with Protovespa and most of the other non-Euparagiinae Vespidae (hindwing subbasal cell broadest subapically, $C u 1$ diverging basad of $c u-a, c u-a$ aligned with A).

This analysis also recovered the monophyly of established tribes and subfamilies. The relationships among extant subfamilies were congruent with previous analyses including mitochondrial and nuclear genes (Pickett \& Carpenter, 2010; Piekarski et al., 2014). Depending on the tree, $C$. striata either clusters with the other Curiosivespa or closer to Priorparagia and Euparagia. The fossil P. anancites is more related to extant Euparagiinae than to the other fossils. Protovespa haxairei is more related to extant non-Euparagiinae Vespidae than to Priorvespinae. In addition to the unresolved Curiosivespa in the consensus, symmetric resampling revealed one unsupported node within the subfamily Polistinae. Support values of the deep nodes were mostly relatively low.

\section{Discussion}

The two Curiosivespa fossils are readily attributed to the Euparagiinae by their specific venation pattern, with the subdiscal cell anteriorly produced. The position of Protovespa haxairei is more problematic. The combination of emarginate eyes, a reduced medio-dorsal part of the pronotum, the pronotum exceeding the tegula dorsally and the first tarsomere of foreleg elongate confirm that this fossil belongs to Vespidae. However, it could not be attributed to Euparagiinae (forewing subdiscal cell not produced), nor Masarini (three submarginal cells) or Gayellini (divergence of hindwing $C u$ basal to $c u-a$ ). It is not a eumenine (claws not bifid, no parategula) and not a social wasp (posterior part of the head more produced dorsally, forewing $1 c u-a$ long, $R s+M$ long relative to $M$ between $M+C u$ and $R s)$. Protovespa has affinities with the Mesozoic subfamily Priorvespinae but with several 
differences concerning the venation (e.g., recurrent veins received in the same cell, $2 r-m$ sinuous, $3 r-m$ not sinuous). This taxon was found to be more related to extant subfamilies (minus Euparagiinae) than Priorvespinae. In order to avoid a paraphyletic definition of Priorvespinae (Fig. 7), Protovespa is attributed to its own subfamily.

Addition of new taxa and characters to the analysis of Carpenter \& Rasnitsyn (1990) modified the position of Priorvespinae within Vespidae. Despite its peculiar combination of plesiomorphic characters (short first discal cell, first abscissa of $R s+M$ longer than $M$ between $R s$ and $M+C u, 3 r-m$ sinuous, first subdiscal cell not elongated dorso-apically and $1 c u-a$ long and curved), Priorvespa is more closely related to the five derived subfamilies of Vespidae than the genus is to Euparagiinae. The affinities between Priorvespa and Protovespa haxairei, combined with the new morphological characters that could relate $P$. haxairei to the Masarinae, Eumeninae and social wasps (retracted metasoma, forewing marginal cell shape and appendix, $1 r-m$ sinuous, hindwing $C u l$ diverging basad of $c u-a$ and $c u-a$ aligned with $A$ ), confirm Priorvespa as a member of Vespidae.

Considering that the oldest Curiosivespa, C. antiqua Carpenter \& Rasnitsyn, had the subdiscal cell distinctly produced apically (Carpenter \& Rasnitsyn, 1990), a clear synapomorphy of Euparagiinae, these wasps already diverged from the other Vespidae by the Hauterivian (129.4-132.9 Myo; Rasnitsyn \& Zherikhin, 2002). The oldest priorvespines date back to the same time, with $P$. bullata Carpenter \& Rasnitsyn, also from Baissa and P. longiceps Carpenter \& Rasnitsyn, of a similar age from Turga in Russia (Rasnitsyn \& Zherikhin, 2002). Thus, the origin of Vespidae occurred prior to these fossils and dates at least from the Hauterivian, but more likely before, in the very early Cretaceous.

The new fossil data suggest that, at the beginning of the Late Cretaceous, the ancestor of social wasps may already have had a metasoma that could be retracted within its second segment. This feature, apparently lost secondarily in Masarini, enables wider telescopic movements important in active breathing, especially at high temperatures (Papachristoforou et al., 2007; Käfer et al., 2013). It may have provided this lineage with an evolutionary advantage in the hot climate of the Cretaceous. Based on the known fossils, Cretaceous wasps also had non-plaited wings at rest, a protuberant scutellum and lateral propodeal extensions. The length of the first discal cell seems to have varied in the early stage of vespid evolution, the cell being somewhat short in Priorvespinae and Protovespinae, but also in some Stenogastrinae (e.g., Liostenogaster topographica Turilazzi,) and Gayellini. Similarly, the connection of the vein $1 c u-a$ at the fork of $M$ and $C u$, an apparent plesiomorphy, is present in these groups and varies within Curiosivespa. 
The existence of a eumenine in the Turonian amber of New Jersey indicates that the divergence between the lineages of Masarinae, Eumeninae and social wasps occurred in the Cretaceous (Carpenter, 2000). Unfortunately, no fossil Masarinae has been found to confirm the timing of these events. The lack of a stenogastrine fossil is also an impediment to the dating of social evolution in the group. The fossil nest Brownichnus Genise was confirmed as belonging to social wasps (Wenzel, 1990; Genise, 2000) and is the only indication that sociality evolved as early as the Late Cretaceous in wasps. Unfortunately, the exact age is ambiguous for this fossil. Most Vespidae fossils were described from the Paleogene, hence offering little resolution of deep relationships within Vespidae. Furthermore, many of these fossils were attributed to extant genera and require taxonomic revisions (see Antropov et al., 2014).

Finally, the low support values for the basal lineages of our analysis suggest that the deep relationships among vespid subfamilies may still be unstable and need further analysis. This result confirms the findings of a previous study, in which relationships among Vespidae subfamilies were found to be highly sensitive to data type and methods (Piekarski et al., 2014). We hope that the new insights provided by the fossils described in this study will lead to inclusion of fossil data in future analyses of the Vespidae, to best infer the evolutionary history of the family.

\section{Acknowledgements}

We thank James Zigras for providing the specimens for this study, Paul Nascimbene for fossil preparation and Stephen Thurston for the microphotographs. We are also grateful to Alexander Rasnitsyn for his help with establishing the list of fossil Vespidae, and to the two anonymous reviewers for their helpful comments on the manuscript. This work was funded by a Gerstner scholarship and a Kalbfleish fellowship to A. P. from the AMNH.

\section{References}

Antropov, A.V., Belokobylskij, S.A., Compton, S.G., Dlussky, G.M., Khalaim, A.I., Kolyada, V.A., Kozlov, M.A., Perfilieva, K.S., and Rasnitsyn, A.P. (2014). The wasps, bees and ants from the insect limestone (Late Eocene) of the Isle of Wight, UK. Earth and Environmental Science Transactions of the Royal Society of Edinburgh 104, 335-446.

Archer, M.E. (2012). Vespine wasps of the world: behaviour, ecology \& taxonomy of the Vespinae. (Siri Scientific Press), 352p. 
Brothers, D.J., and Rasnitsyn, A.P. (2008). A new genus and species of Euparagiinae from the Late Cretaceous of southern Africa (Hymenoptera: Vespidae). Alavesia 2, 73-76.

Carpenter, J.M. (1981 [1982]). The phylogenetic relationships and natural classification of the Vespoidea (Hymenoptera). Systematic Entomology 7, 11-38.

Carpenter, J.M. (2000). A vespid wasp from New Jersey Cretaceous amber. In: Studies on fossils in amber, with particular reference to the Cretaceous of New Jersey. D. Grimaldi (Ed). Backhuys Publishers, Leiden, The Netherlands. pp333-337.

Carpenter, J.M., and Kimsey, L.S. (2009). The genus Euparagia Cresson (Hymenoptera: Vespidae; Euparagiinae). American Museum Novitates 3643, 1-11.

Carpenter, J.M., and Rasnitsyn, A.P. (1990). Mesozoic Vespidae. Psyche 97, 1-20.

Genise, J.F. (2000). The ichnofamily Celliformidae for Celliforma and allied ichnogenera. Ichnos: An International Journal of Plant \& Animal 7, 267-282.

Goloboff, P.A. (1993). Estimating character weights during tree search. Cladistics 9, 83-91.

Goloboff, P.A., Farris, J.S., Källersjö, M., Oxelman, B., Szumik, C.A. (2003). Improvements to resampling measures of group support. Cladistics 19, 324-332.

Goloboff, P.A., Farris, J.S., and Nixon, K.C. (2008). TNT, a free program for phylogenetic analysis. Cladistics 24, 774-786.

Grimaldi, D., and Ross, A.S. (2016) Extraordinary Lagerstaetten in amber, with particular reference to the Cretaceous of Burma. In: Terrestrial Conservation Lagerstätten: Windows into the Evolution of Life on Land. N.C. Fraser, and H.-D. Sues (Eds). Dunedin Press, Edinburgh, UK.

Hines, H.M., Hunt, J.H., O’Connor, T.K., Gillespie, J.J., and Cameron, S.A. (2007). Multigene phylogeny reveals eusociality evolved twice in vespid wasps. Proceedings of the National Academy of Sciences 104, 3295-3299.

Käfer, H., Kovac, H., and Stabentheiner, A. (2013). Respiration patterns of resting wasps (Vespula sp.). Journal of Insect Physiology 59, 475-486.

Papachristoforou, A., Rortais, A., Zafeiridou, G., Theophilidis, G., Garnery, L., Thrasyvoulou, A., and Arnold, G. (2007). Smothered to death: Hornets asphyxiated by honeybees. Current Biology 17, R795-R796.

Piekarski, P.K., Longair, R., and Rogers, S. (2014). Monophyly of eusocial wasps (Hymenoptera:Vespidae): molecules and morphology tell opposing histories. Journal of Undergraduate Research in Alberta 4, 11-14.

Pickett, K.M., and Carpenter, J.M. (2010). Simultaneous analysis and the origin of eusociality in the Vespidae (Insecta: Hymenoptera). Arthropod Systematics \& Phylogeny 68, 3-33. 
Rasnitsyn, A.P., and Zherikhin, V.V. (2002). Impression fossils. History of Insects. (Kluwer Academic Publishers), 444p.

Ross, K.G., and Matthews, R.W. (1991). The social biology of wasps (Cornell University Press). $678 \mathrm{p}$.

Shi, G., Grimaldi, D.A., Harlow, G.E., Wang, J., Wang, J., Yang, M., Lei, W., Li, Q., and Li, X. (2012). Age constraint on Burmese amber based on $\mathrm{U}-\mathrm{Pb}$ dating of zircons. Cretaceous Research 37, 155-163.

Turillazzi, S. (2012). The biology of hover wasps (Springer-Verlag Berlin Heidelberg), 272p.

Turillazzi, S., and West-Eberhard, M.J. (1996). Natural history and evolution of paper-wasps (Oxford University Press Oxford), 400p.

Wenzel, J.W. (1990). A social wasp's nest from the Cretaceous period, Utah, USA, and its biographical significance. Psyche 97, 21-29. 


\section{FIGURES:}

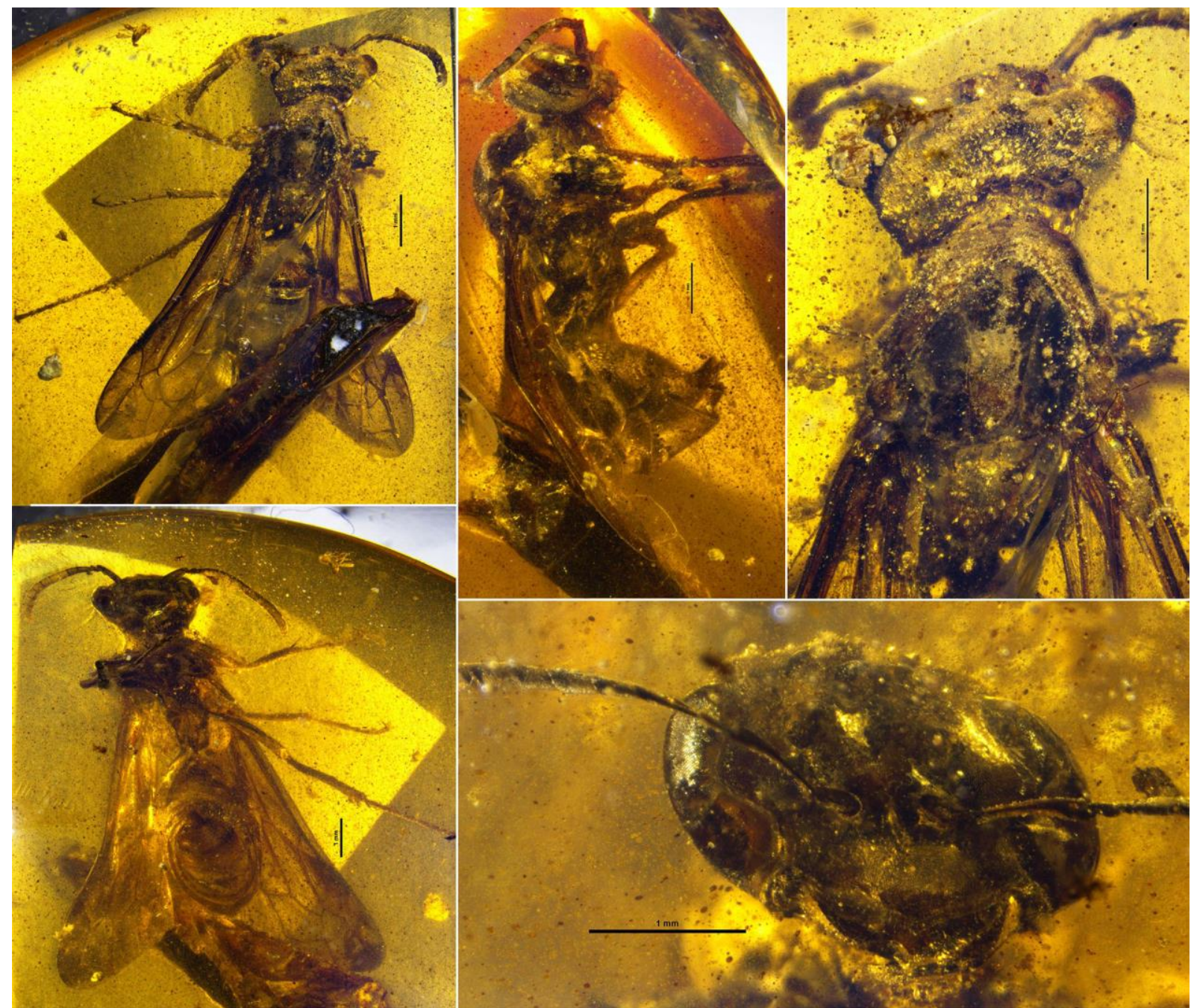

Figure 1. Holotype of Protovespa haxairei. Scale bars indicate $1 \mathrm{~mm}$. From top right to bottom left: dorsal habitus; right lateral habitus; head and thorax, dorsal; habitus, ventral; head, frontal view 

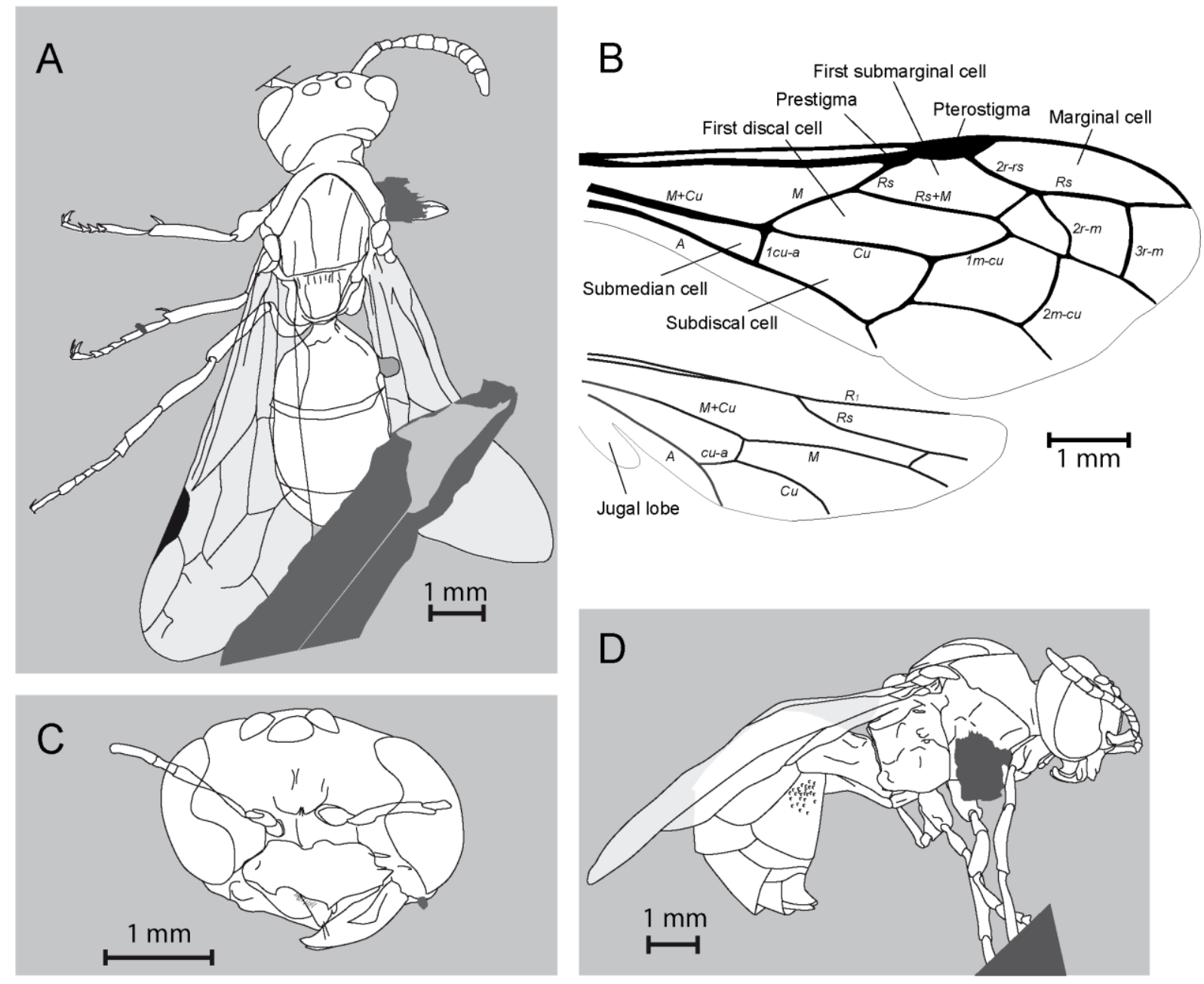

Figure 2. Details of the holotype of Protovespa haxairei. A: dorsal view. B: right wings, venation. C: frontal view of the head. D: lateral view. Parts obscured due to debris, bubbles, or surface of the amber are shaded in dark grey.

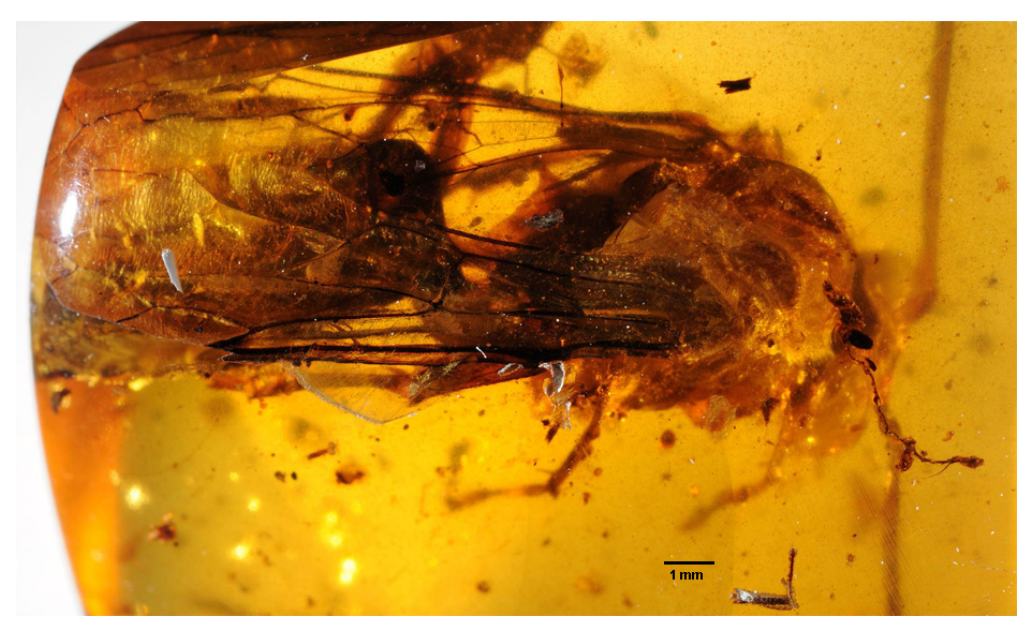

Figure 3. Holotype of Curiosivespa zigrasi. Scale bar indicates $1 \mathrm{~mm}$. 

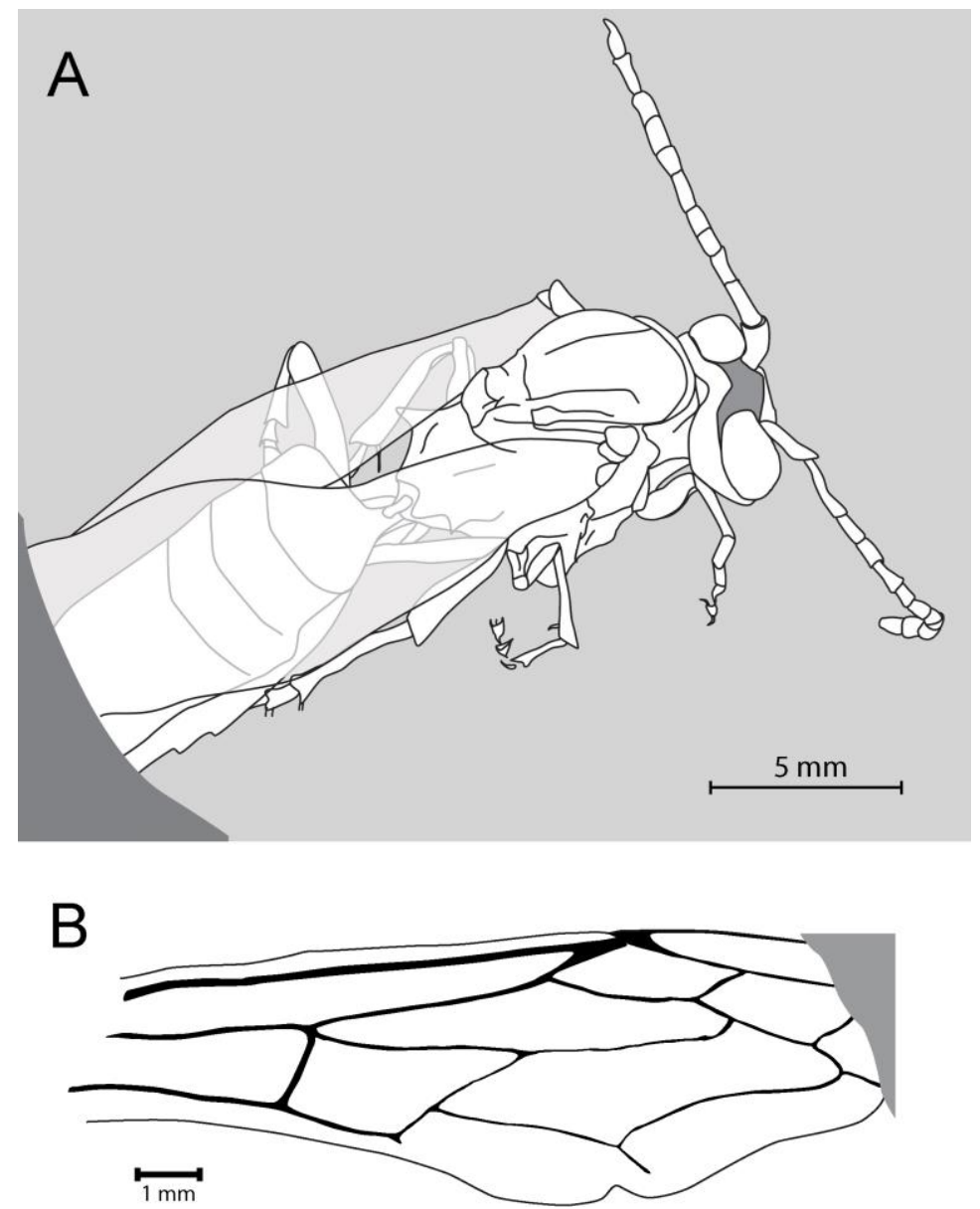

Figure 4. Details of Curiosivespa zigrasi. A: dorsal view. B: right forewing venation. Obscured parts are shaded in dark grey.

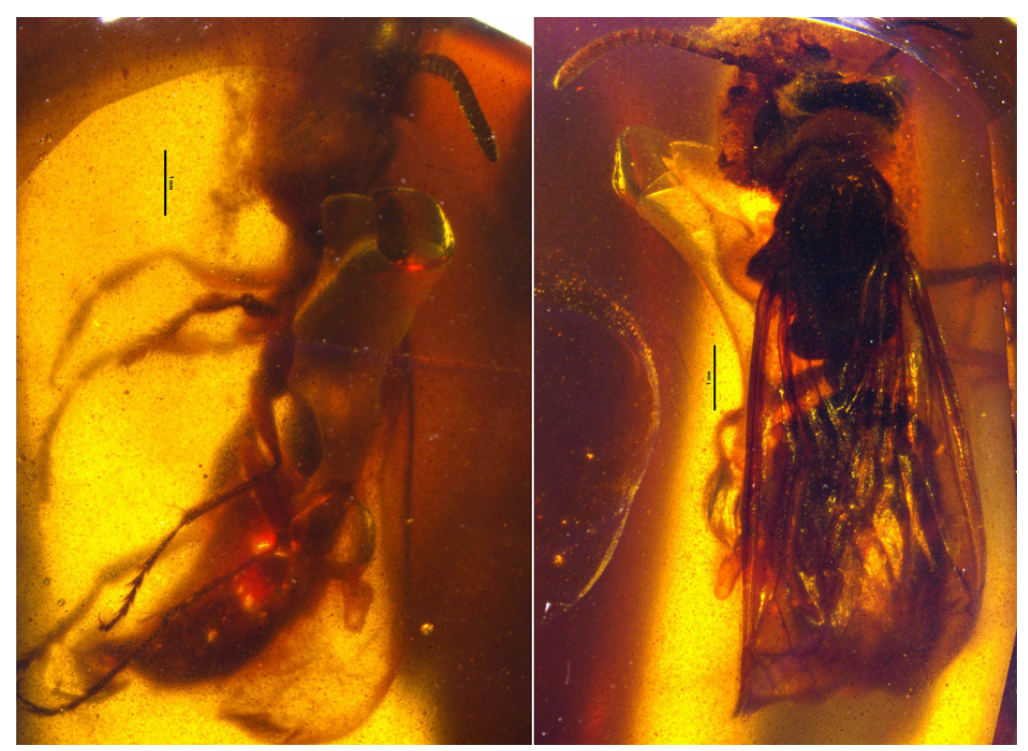

Figure 5. Holotype of Curiosivespa striata. Scale bars indicate $1 \mathrm{~mm}$. 


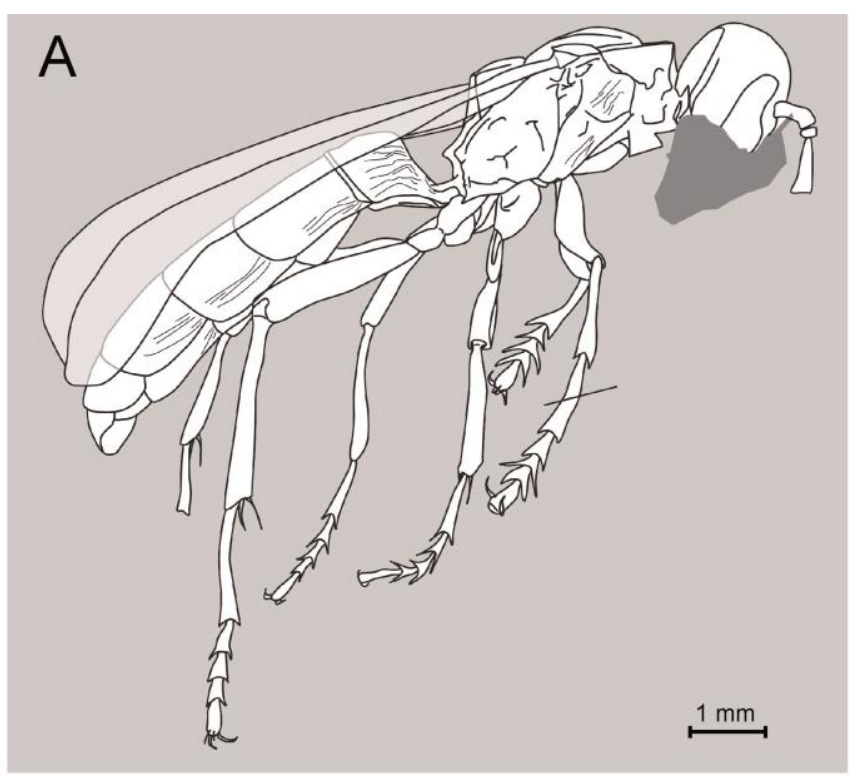

B

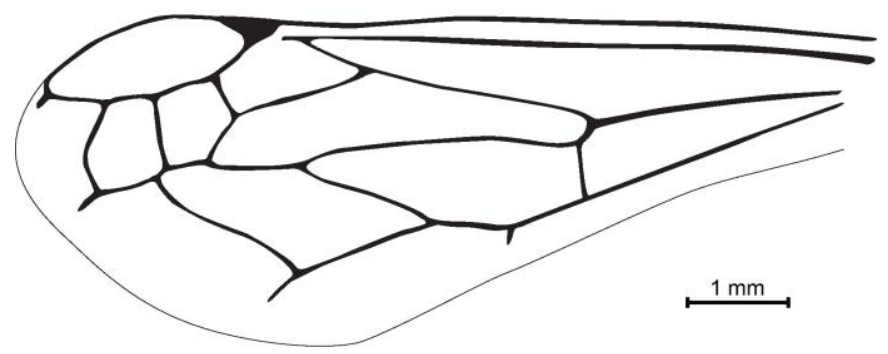

Figure 6. Details of Curiosivespa striata. A: Lateral view. B: left forewing. Obscured parts are shaded in dark grey. 


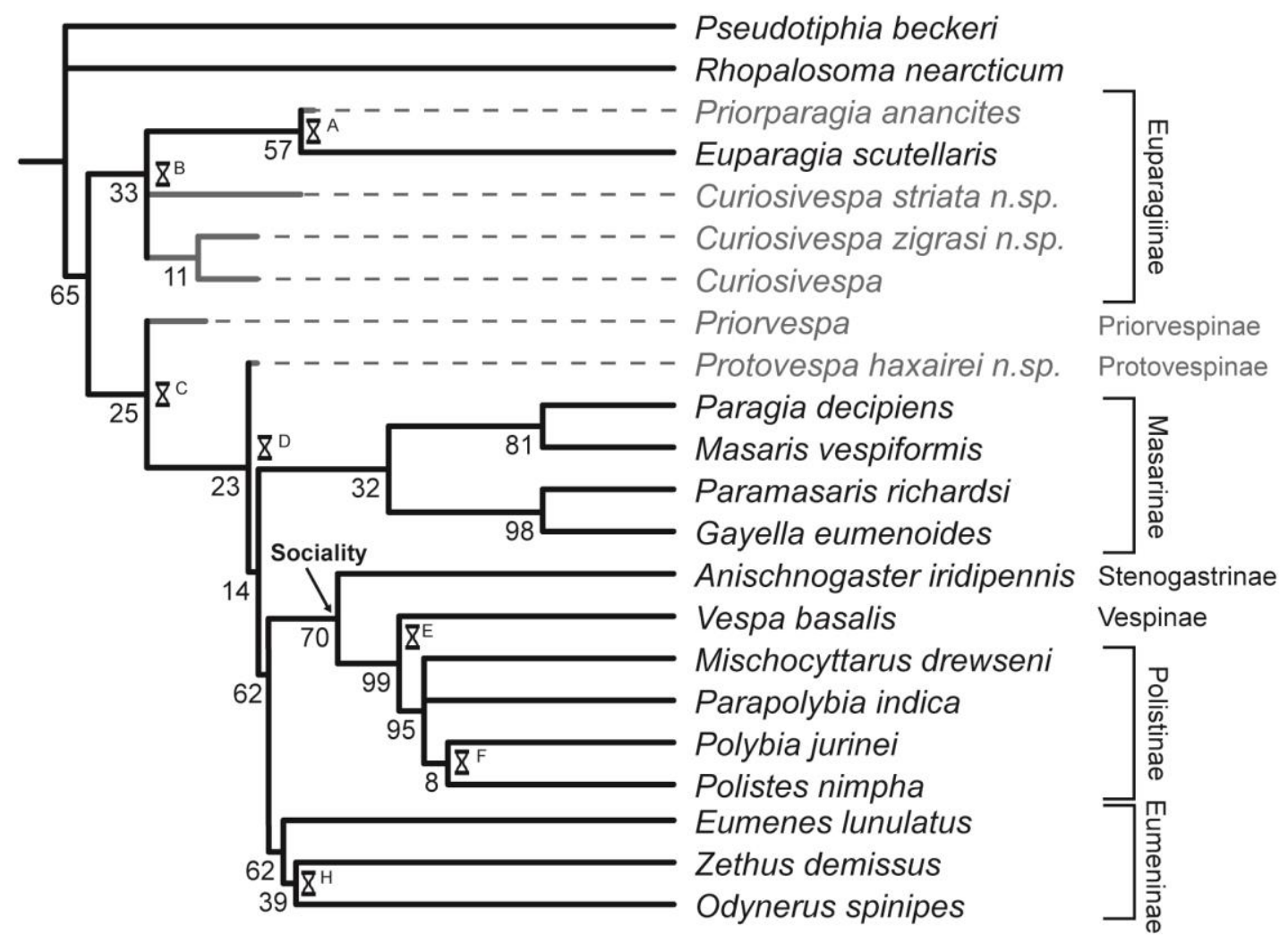

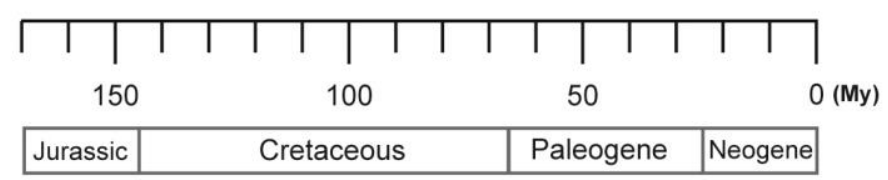

Z Node dated using fossils (minimum age in My)

A Priorparagia anancites (86) $\mathrm{E}_{\text {Brownichnus favosites (66) }}$

${ }^{\mathrm{B}}$ Curiosivespa antiqua (129) $\mathrm{F}$ Polistes vergnei (54.8)

${ }^{\mathrm{C}}$ Priorvespa longiceps (129) ${ }^{\mathrm{G}}$ Symmorphus senex (89.8)

D Protovespa haxairei (98)

Figure 7. Chronogram of the evolution of the Vespidae. Relationships among taxa are based on the consensus of the two most parsimonious trees resulting from the analysis of 75 characters with implied weighting. Only supported nodes (GC-value $>0$ ) are shown. Time scale is in millions of years. Fossil taxa and extinct lineages are depicted in grey. Fossil branches end at the youngest possible age of the most recent fossil known for the corresponding taxon. Only nodes marked by an hourglass are dated and to be compared to the timeline. The age of these nodes is based on the youngest possible age of the earliest fossil of the clade. 


\section{Supplementary material}

Table S.1. Table of the Vespidae found in the fossil record. The list is in chronological order, from the most recent to the most ancient species. ' $\mathrm{N}$ ' indicates species described based on fossil nests.

\begin{tabular}{|c|c|c|c|c|c|}
\hline Genus & Species & Author, date & Deposit & Geological period & Country \\
\hline Polistes & kirbyanus & Cockerell, 1914 & Oeningen & Sarmatian & Germany \\
\hline Polistes & primitiva & Heer, 1865 & Oeningen & Sarmatian & Germany \\
\hline Polistes & attavinus & (Heer, 1849) & Parschlug & Miocene & Austria \\
\hline Agelaia & electra & Carpenter \& Grimaldi, 1997 & Dominican amber & Miocene & Dominican Rep. \\
\hline Eumenes & shanwangensis & (Hong, 1983) & Shanwang & Middle Miocene & China \\
\hline Rotundipetiolus & longiantennus & Zhang, 1989 & Shanwang & Middle Miocene & China \\
\hline Harmorhynchium & reflexum & Zhang et al., 1994 & Shanwang & Middle Miocene & China \\
\hline Provespa & nobilis & Zhang et al., 1994 & Shanwang & Middle Miocene & China \\
\hline Vespa & ciliate & Zhang et al., 1994 & Shanwang & Middle Miocene & China \\
\hline Vespa & picea & Zhang et al., 1994 & Shanwang & Middle Miocene & China \\
\hline Vespa & crabroniformis & Heer, 1867 & Radoboj & Lower Miocene & Croatia \\
\hline Alastor & rottensis & (Meunier, 1915) & Rott & Rupelian & Germany \\
\hline Eunortonia & sepulta & (Timon-David, 1944) & Camoins-les-Bains & Rupelian & France \\
\hline Polistes & signata & Statz, 1936 & Rott-am & Rupelian & Germany \\
\hline Vespa & bilineata & Statz, 1936 & Rott-am & Rupelian & Germany \\
\hline Vespa & cordifera & Statz, 1936 & Rott-am & Rupelian & Germany \\
\hline Vespa & nigra & Statz, 1936 & Rott-am & Rupelian & Germany \\
\hline Odynerus & oligopunctatus & Theobald, 1937 & Cereste & Rupelian & France \\
\hline Polistes & industrius & Theobald, 1937 & Cereste & Rupelian & France \\
\hline Odynerus & palaeophilus & Cockerell, 1906 & Florissant & Rupelian & U.S.A. \\
\hline Odynerus & praesepultus & Cockerell, 1906 & Florissant & Rupelian & U.S.A. \\
\hline Odynerus & terryi & Cockerell, 1909 & Florissant & Rupelian & U.S.A. \\
\hline Odynerus & percontusus & Cockerell, 1914 & Florissant & Rupelian & U.S.A. \\
\hline Odynerus & wilmattae & Cockerell, 1914 & Florissant & Rupelian & U.S.A. \\
\hline Palaeovespa & florissantia & Cockerell, 1906 & Florissant & Rupelian & U.S.A. \\
\hline Palaeovespa & gillettei & Cockerell, 1906 & Florissant & Rupelian & U.S.A. \\
\hline Palaeovespa & relecta & Cockerell, 1923 & Florissant & Rupelian & U.S.A. \\
\hline Palaeovespa & scudderi & Cockerell, 1906 & Florissant & Rupelian & U.S.A. \\
\hline Palaeovespa & wilsoni & Cockerell, 1914 & Florissant & Rupelian & U.S.A. \\
\hline$N$-Eumenes & roemeri & Handlirsch, 1910 & Flörsheim & Rupelian & Germany \\
\hline Palaeopolybia & anglica & (Cockerell, 1921) & Gurnard Bay & Oligoc. - Eocene & U.K. \\
\hline Protopolistes & oblita & (Cockerell, 1921) & Gurnard Bay & Oligoc. - Eocene & U.K. \\
\hline Sphaerancistrocerus & petiolatus & Antropov, 2014 & Gurnard Bay & Oligoc. - Eocene & U.K. \\
\hline Palaeopolistes & jattioti & Perrard, 2014 & Monteils & Upper Eocene & France \\
\hline Alastor & solidescens & (Scudder, 1890) & Green River Beds & Eocene & U.S.A. \\
\hline Palaeovespa & baltica & Cockerell, 1909 & Baltic & Eocene & Baltic \\
\hline Palaeovespa & socialis & Poinar Jnr, 2005 & Baltic & Eocene & Baltic \\
\hline Vespa & dasypodia & Menge, 1856 & Baltic & Eocene & Baltic \\
\hline Paleovespa & menatensis & Nel \& Auvray, 2006 & Menat & Paleocene & France \\
\hline Ancistrocerus & berlandi & Piton, 1940 & Menat & Paleocene & France \\
\hline Ancistrocerus & eocenicus & Piton, 1940 & Menat & Paleocene & France \\
\hline Eumenes & projaponica & Piton, 1940 & Menat & Paleocene & France \\
\hline Odynerus & manevali & Piton, 1940 & Menat & Paleocene & France \\
\hline Polistes & vergnei & Piton, 1940 & Menat & Paleocene & France \\
\hline Rhynchium & andrei & Piton, 1940 & Menat & Paleocene & France \\
\hline$N-$ Brownichnus & favosites & (Brown, 1941) & Utah & Upper Cretaceous & U.S.A. \\
\hline Curiosivespa & orapa & Brothers, 1992 & Orapa & Coniacian-Cenomanian & Botswana \\
\hline Priorparagia & anancites & Brothers \& Rasnitsyn, 2008 & Orapa & Coniacian-Cenomanian & Botswana \\
\hline Curiosivespa & curiosa & Rasnitsyn, 1975 & Kzyl-Zhar & Turonian & Kazakhstan \\
\hline Symmorphus & senex & Carpenter, 2000 & New Jersey & Turonian & U.S.A. \\
\hline Curiosivespa & zigrasi & Perrard \& Carpenter, 2016 & Burmese amber & late Albian & Myanmar \\
\hline Curiosivespa & striata & Perrard \& Carpenter, 2016 & Burmese amber & late Albian & Myanmar \\
\hline Protovespa & haxairei & Perrard \& Carpenter, 2016 & Burmese amber & late Albian & Myanmar \\
\hline Curiosivespa & derivata & Carpenter \& Rasnitsyn, 1990 & Bon-Tsagan & Aptian & Mongolia \\
\hline Priorvespa & directa & Carpenter \& Rasnitsyn, 1990 & Bon-Tsagan & Aptian & Mongolia \\
\hline Priorvespa & minuta & Carpenter \& Rasnitsyn, 1990 & Bon-Tsagan & Aptian & Mongolia \\
\hline Priorvespa & quadrata & Carpenter \& Rasnitsyn, 1990 & Bon-Tsagan & Aptian & Mongolia \\
\hline Priorvespa & recidiva & Carpenter \& Rasnitsyn, 1990 & Bon-Tsagan & Aptian & Mongolia \\
\hline Priorvespa & longiceps & Carpenter \& Rasnitsyn, 1990 & Turga & Hauterivian & Russia \\
\hline Curiosivespa & antiqua & Carpenter \& Rasnitsyn, 1990 & Baissa & Hauterivian & Transbaikalia \\
\hline Priorvespa & bullata & Carpenter \& Rasnitsyn, 1990 & Baissa & Hauterivian & Transbaikalia \\
\hline
\end{tabular}




\section{References for table S1:}

Antropov, A. V., Belokobylskij, S. A., Compton, S. G., Dlussky, G. M., Khalaim, A. I., Kolyada, V. A., Kozlov M. A., Perfilieva K. S. \& Rasnitsyn, A. P. (2014). The wasps, bees and ants (Insecta: Vespida= Hymenoptera) from the insect limestone (Late Eocene) of the Isle of Wight, UK. Earth and Environmental Science Transactions of the Royal Society of Edinburgh, 104(3-4), 335-446.

Brothers, D. J., \& Rasnitsyn, A. P. (2008). A new genus and species of Euparagiinae from the Late Cretaceous of southern Africa (Hymenoptera: Vespidae). Alavesia, 2, 73-76.

Brothers, D. J. (1992). The first Mesozoic Vespidae from the southern hemisphere, Botswana. Journal of Hymenoptera Research, 1, 119-124.

Brown, R. W. (1941). The comb of a wasp nest from the Upper Cretaceous of Utah. American Journal of Science, 239(1), 54-56.

Carpenter, J. M., \& Rasnitsyn, A. P. (1990). Mesozoic Vespidae. Psyche, 97(1-2), 1-20.

Carpenter, J. M., \& Grimaldi, D. A. (1997). Social wasps in amber. American Museum Novitates, $3203,1-7$.

Carpenter J. M. (2000). A vespid wasp from New Jersey Cretaceous amber. In Grimaldi D. A. (ed.) Studies on fossils in amber, with particular reference to the Cretaceous of New Jersey, 333-37. Leiden, The Netherlands: Backhuys.

Cockerell, T. D. A. (1906). Fossil Hymenoptera from Florissant, Colorado. Bulletin of the Museum of Comparative Zoology, 50, 33-58.

Cockerell, T. D. A. (1909). Description of Hymenoptera from Baltic Amber. Schriften der Physikalisch-ökonomischen Gesellschaft, Königsberg, 50, 1-20.

Cockerell, T. D. A. (1909). New Fossil Insects from Florissant, Colorado. Annals of the Entomological Society of America, 2(4), 251-256.

Cockerell, T. D. A. (1914). Miocene fossil insects. Proceedings of the Academy of Natural Sciences of Philadelphia, 634-648.

Cockerell, T. D. A. (1921). Fossil Arthropods in the British Museum.-V. Oligocene Hymenoptera from the Isle of Wight. Journal of Natural History, 7(37), 1-25.

Cockerell, T. D. A. (1921). Fossil Arthropods in the British Museum.-VII. Journal of Natural History, 8(47), 541-545.

Cockerell, T. D. A. (1923). Two fossil Hymenoptera from Florissant (Vespidae, Megachilidae). Entomological News, 34, 270-271.

Genise, J. F. (2000). The ichnofamily Celliformidae for Celliforma and allied ichnogenera. Ichnos: An International Journal of Plant \& Animal, 7(4), 267-282.

Handlirsch, A. (1910). Canadian Fossil Insects. Contributions to Canadian Palaeontology, 2, 93129.

Heer, O. (1849). Die Insektenfauna der Tertiärgebilde von Oeningen und Rodoboj in Croatien : Zweite Abtheilung: Heuschrecken, Florfliegen, Aderflügler, Schmetterlinge und Fliegen. Neue Denkschriften der allgemeinen Schweizerischen fur die gesammten.

Natürwissenschaften, 11, 1-264.

Heer, O. (1865). Die Urwelt der Schweiz. Zürich: Friedrich Schulthess.

Heer, O. (1867). Fossile Hymenopteren aus Oeningen und Radoboj. Neue Denkschriften der allgemeinen Schweizerischen fur die gesammten. Natürwissenschaften, 22, 1-42.

Hong, Y. C. (1983). Fossil insects in the diatoms of Shanwang. Bulletin of the Tianjin Institute, Geology and Mineral Resources, 8, 1-11.

Menge, A. (1856). Lebenszeichen vorweltlicher, im Bernstein eingeschlossener Theire. Oeffentl. Progr. d. Petrischule in Danzig, 2, 1-32.

Meunier, F. (1915). Über einige fossile Insekten aus den Braunkohlenschichten (Aquitanien) von Rott (Siebengebirge). Zeitschrift der deutschen geologischen Gesellschaft, 205-217. 
Nel, A., \& Auvray, F. (2006). The oldest Vespinae from the Paleocene of Menat (France)(Hymenoptera: Vespidae). Zootaxa, 1344, 59-62.

Perrard, A., Nel, A., \& Carpenter, J. M. (2014). A new paper wasp from Late Eocene of France (Hymenoptera: Vespidae: Polistinae). Zootaxa, 3753(6), 542-548.

Piton, L. E. (1940). Paleontologie du gisement eocene de Menat. Memoires de la societe d'histoire naturelle d'Auvergne, 1, 1-303.

Poinar Jnr, G. (2005). Fossil Trigonalidae and Vespidae (Hymenoptera) in baltic amber. Proceedings of the Entomological Society of Washington, 107(1), 55-63.

Rasnitsyn, A. P. (1975). Hymenoptera apocrita of the Mesozoic. Trudy Paleontologicheskogo Instituta, Akademii Nauk SSSR [Transactions of the Paleontological Institute, Academy of Sciences USSR], 147, 1-132.

Scudder, S. H. (1890). The Tertiary insects of North America. Rep. U.S. Geol. Surv, 13, 1-734.

Statz, G. (1936). Ueber alte und neue fossile Hymenopteren-funde aus den tertiaren Ablagerungen von Rott aus Siebengebirge. Decheniana, 93, 280-282.

Theobald, N. (1937). Les insectes fossiles des terrains Oligocenes de France. Bulletin de la Societe des Sciences de Nancy, 2, 1-467.

Timon-David, J. (1944). Insectes fossiles de l'Oligocene inférieur des Camoins (Bassin de Marseille). II. Hyménopteres. Bulletin de la Société entomologique de France, 49, 40-45.

Zhang, J. F., (1989). Fossil Insects from Shanwang, Shandong, China. Shandong Science and Technology Publishing House, Jinan, China.

Zhang, J. F., Sun, B. \& Zhang, X. Y. (1994). Miocene Insects and Spiders from Shanwang, Shandong. Science Press, Beijing, China. 


\section{Table S2. Matrix and list of the morphological and behavioural characters.}

'?' refers to missing data; '-' refers to non-applicable character; '\#' refers to multistate characters ' 0 and 1 '; ' $*$ ' refers to multistate characters ' 1 and 2'. Curiosivespa and Priorvespa were scored on the basis of every known fossil for these taxa. Fossil taxa are in grey. Characters 06, 24, 38, $39,48,56,60$ and 74 were treated as additive.

TAXA CHARACTERS Rhopalosoma_nearcticum Priorvespa Protovespa_haxairei Euparagia_scutellaris Curiosivespa Curiosivespa_striata Curiosivespa_zigrasi Priorparagia_anancites Gayella_eumenoides Masaris_vespiformis Paramasaris_richardsi Paragia_decipiens Zethus_demissus Eumenes_Lunulatus odynerus spinipes Anischnogaster_iridipennis Polistes_nimpha Mischocyttarus_drewsenii Parapolybia_indica Polybia jurinei Vespa_basalis
000000000011111111112222222222333333333344444444445555555555666666666677777 $01234567890123456789 \quad 0123456789 \quad 01234567890123456789 \quad 0123456789012345678901234$ $0000020000100000000000012011000200000001000-0 \# 01110---0--1-0--1111000000000$ $11100-000100000010000000000001010010000000000100200-1-1--1-0200001101000000$ ?01???00?? ?0???01??? ?01????1?? 1???????2100000001100100100010 20?\#0?2101 ????? 00100 ?0*01 10???11011 0011201111 11011 ???21 00100101100011110101 2100012101 ?0??? $001101 * 20 \# 10000110110011201111100000102100011011010010000010001100100000000$ 0110 ??\#0?1 00???11??? 001?2?1??? 1???????2* 0001110\#\#1 0000\#\#\#10 \#0\#0??100? ?????

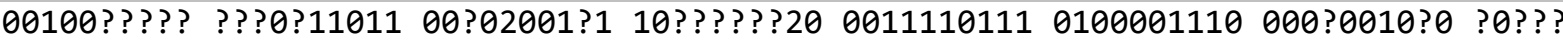

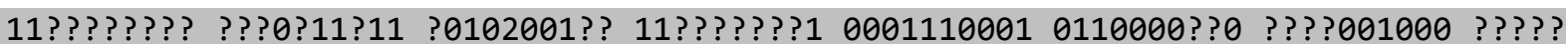

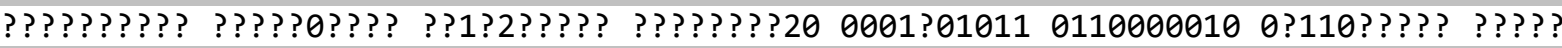
0011002100101011111110110111101101100021001101011 \# 0010100101100001000111010 00110-1301 $10101111111001211110110000101 \# 0110110110$ 0-1-1-00-1 101000221111010 $001100220010101111111001211110110110002100110100100010100101 \quad 100001000111010$ $00001010010010111111001121111011001010100110110120 \quad 0-1-1-0010001000221111010$ 001001030010100111110111110111121110002011111101001001110110001000210111000 $001101230100100111110101011111 \quad 121110002011111101101011110100101000210111000$ 001\#011301 10100111110101111111121100002011111101101011110110001000210111000 $101012210010000110110010001011 \quad 1111100021011111011011111101012110102101 \quad 11101$ $101011111010110111111000000111 \quad 101111112011111100201021111110211000210111102$ $00101-111010110111110000000011 \quad 101111112011111101201021111110211000210111102$ $001011111010110111110000000011 \quad 101111112011111101201021112110211000210111102$ $00101111101011011111 \quad 1000000111 \quad 1011111120111111012010201121102110002101 \quad 11102$ 001011130011110111010000101011101111112011111100201021110100211100210121102 
00 Scape: $0=$ longer than 1 st flagellum; $1=$ shorter than 1st flagellum.

01 Flagellum articles: $0=$ short (length width); 1 = long (length >>width).

02 Eyes: $0=$ with interior margin straight or slightly curved; $1=$ emarginate.

03 Posterior ocelli: $0=$ closer to each other than to the eyes; $1=$ closer to the eyes than to each other.

04 Gena width: $0=$ upper part > lower part;

$1=$ lower part $>$ or $=$ upper part.

05 Preoccipital and postocular carinae:

$0=$ present and separated; $1=$ fused;

$2=$ evanescent.

06 Clypeus shape: $0=$ wider than long; $1=$ square; $2=$ longer than wide.

07 Clypeus apex: $0=$ continuous; median tooth; $1=$ two central teeth; $2=$ two lateral teeth.

08 Lateral lobes of clypeus: $0=$ absent or reduced; $1=$ pronounced.

09 Labrum: $0=$ hidden; 1 = protruding.

10 Labrum apex: $0=$ wide (similar width to clypeus apical area); $1=$ narrow $(<1 / 2$ width than clypeus apical area).

11 Mandible: $0=$ with small cutting edge; $1=$ with long cutting edge.

12 Acroglossal buttons: $0=$ absent; $1=$ present.

13 Posterior lingual plate: $0=$ narrow; $1=$ broad.

14 Hypostomal apodemes: $0=$ absent; $1=$ present.

15 Mesosoma shape: $0=$ short or as long as wide; $1=$ longer than wide.

16 Pronotum dorsum: $0=$ long (horizontal part $>1 / 4$ of length mesonotum); $1=$ short (horizontal part absent or $<1 / 4$ of mesonotum).

17 Pronotal carina: $0=$ absent; $1=$ present. 18 Posterior pronotal lobe: $0=$ next to the tegula; $1=$ distinctly distant from the tegula (from $\sim 1 / 2 \mathrm{x}$ length of the lobe to $3 \mathrm{x}$ length of the lobe).

19 Prescutal sculpture: $0=$ absent;
$1=$ present.

20 Tegula shape: $0=$ about as long as wide;

$1=$ distinctly elongated.

21 Parategula: $0=$ absent; $1=$ present.

22 Pronotum posterior angle: $0=$ stopping at the tegula; $1=$ produced above the tegula.

23 Transscutal furrow: $0=$ smooth;

$1=$ ridged.

24 Metanotum: $0=$ roughly aligned with scutellum; mostly vertical but no overlap with scutellum; 1 = mostly vertical and partially under scutellum, scutellum produced.

25 Scutal lamella: $0=$ present; $1=$ absent.

26 Propodeum posterior part: $0=$ not vertical (angle with mesonotum dorsum > $\left.110^{\circ}\right)$;

$1=$ vertical (angle with mesonotum dorsum $<$ or $\left.=110^{\circ}\right)$.

27 Propodeum posterolateral angles:

0 = blunt, without clear delimitation of lateral and posterior parts; $1=$ sharp (sometime produced), clearly delimited.

28 Mesosternal sclerite before mid-legs:

$0=$ large and produced; $1=$ short and rounded.

29 Trochantellus: $0=$ absent; $1=$ present.

30 First tarsomere: $0=$ length $<$ or $=2 x$ 2nd tarsomere; $1=$ length $>2 \mathrm{x} 2$ nd tarsomere.

31 Claws: $0=$ simple; $1=$ with a basal small tooth; $2=$ bifid.

32 First metasomal segment: $0=$ tergum and sternum distinct; $1=$ tergum and sternum fused.

33 Metasomal retraction: $0=$ absent; $1=$ present.

34 Sixth metasomal sternum: $0=$ apical part straight or slightly curved; 1 = apical part laterally compressed in a furrow.

35 Van der Vecht's gland: $0=$ absent; $1=$ present.

36 Parameral spines: $0=$ elongated; $1=$ short. 
37 Volsella: $0=$ no apodeme; $1=$ apodeme present.

38 Forewing, number of closed cells: $0=$ 7 cells; $1=8$ cells; $2=9$ cells.

39 Forewing, $M$ connection with $\mathrm{Cu}$ :

$0=$ before $\mathrm{Cu}$ and $1 \mathrm{cu}-\mathrm{a} ; 1=$ at the same point; after.

40 Forewing, longitudinal plaiting:

$0=$ absent; 1 = present.

41 Forewing, 1cu-a length: $0=$ long, more than $3 x$ its width; $1=$ short.

42 Forewing, 1cu-a shape: $0=$ curved;

$1=$ straight.

43 Forewing, RsM: 0 = longer than $M$ between $\mathrm{MCu}$ and Rs; 1 = same length or shorter.

44 Forewing, first discal cell: $0=$ shorter than submedian cell; 1 = at least the equal of submedian cell.

45 Forewing, basal angle of first submarginal cell: $0=$ obtuse; $1=$ acute.

46 Forewing, first Rs abscissa: $0=$ long;

$1=$ short.

47 Forewing, pterostigma size: $0=$ short ( $<$ or $=1 / 4$ th of marginal cell length $) ; 1=$ long (> 1/4th of marginal cell length).

48 Forewing, pterostigma shape: $0=$ truncate apically; $1=$ subtruncate, basal angle of marginal cell acute; pointed apically.

49 Forewing, 2nd segment of $\mathrm{Cu}$ :

$0=$ distinctly angled with $1 \mathrm{~m}-\mathrm{cu} ; 1=$ in the prolongation of $1 \mathrm{~m}$-cu.

50 Forewing, vein alignment: $0=$ absent;

$1=\mathrm{MCuA}, \mathrm{CuA}, \mathrm{m}-\mathrm{cu} 1$ and $\mathrm{M}$ aligned in almost straight line.

51 Forewing, second submarginal cell shape: $0=$ narrowed above; $1=$ quadrate.

52 Forewing, second submarginal cell:

$0=$ basal angle obtuse, $M$ and Rs angled;

$1=$ basal angle acute, $M$ and Rs angled;

2 = basal angle obtuse, $M$ and Rs aligned.

53 Forewing, 1r-m: 0 = straight or curved; $1=$ sinuous.

54 Forewing, first recurrent vein: $0=$ distal part angled sharply into second submarginal cell; 1 = distal part running straight into second submarginal cell.

55 Forewing, 1r-m connection to $M$ :

$0=$ before $2 \mathrm{~m}$-cu; $1=$ after $2 \mathrm{~m}$-cu.

56 Forewing, $M$ segment between 1m-cu and 2m-cu: $0=$ longer than between Rs and $1 \mathrm{~m}-\mathrm{cu} ; 1=$ same length; 2 = shorter.

57 Forewing, third submarginal cell:

$0=$ apically rounded; $1=$ apically subtruncate.

58 Forewing, Rs between 1r-m and 2r-m: $0=$ longer than 2r-rs; $1=$ same size or shorter.

59 Forewing, marginal cell shape: $0=\mathrm{Rs}$ angled near middle of cell; $1=$ Rs angled close to pterostigma, then straight.

60 Forewing, marginal cell apex: $0=$ short and rounded; $1=$ elongated and rounded;

2 = elongated with apex pointed.

61 Forewing, marginal cell appendix:

$0=$ present $; 1=$ absent.

62 Forewing, $M$ vein: $0=$ almost reaches the margin; 1 = stops shortly after the 3rd submarginal cell.

63 Forewing, Cu vein: $0=$ almost reaches the margin; $1=$ stops shortly after the cell.

64 Hindwing, cell number: $0=$ three; $1=$ two.

65 Hindwing, hamuli placement:

0 = beginning basad of fork of R1 and Rs;

$1=$ beginning at fork.

66 Hindwing, Cu1: $0=$ diverging apicad of cu-a; $1=$ diverging at cu-a; $2=$ diverging basad of cu-a.

67 Hindwing, cu-a: $0=$ transverse; $1=$ aligned with $\mathrm{A} ; 2$ = angled with apex of $\mathrm{A}$.

68 Hindwing, apical part of hindwing anal vein: $0=$ free; $1=$ fused with cu-a.

69 Hindwing, subbasal cell: $0=$ broadest apically; 1 = broadest subapically.

70 Hindwing, preaxillary excision:

$0=$ shallow; 1 = deep; 2 = absent.

71 Hindwing, anal lobe: $0=$ long; $1=$ short or absent.

72 Larva, clypeus: 0 = broad; $1=$ narrow. 
73 Provisions: $0=$ insects; $1=$ pollen.

74 Sociality: $0=$ solitary; $1=$ temporary

eusociality; 2 = permanent eusociality. 
